medRxiv preprint doi: https://doi.org/10.1101/2022.01.06.22268834; this version posted January 6, 2022. The copyright holder for this preprint (which was not certified by peer review) is the author/funder, who has granted medRxiv a license to display the preprint in perpetuity.

It is made available under a CC-BY-NC-ND 4.0 International license .

\title{
Association between child sexual abuse and mid-life employment earnings.
}

Samantha Bouchard, B.A., ${ }^{1}$ Rachel Langevin, Ph.D., ${ }^{1}$ Francis Vergunst, Ph.D., ${ }^{2,3}$ Melissa Commisso, M.A., ${ }^{4}$ Pascale Domond, Ph.D., ${ }^{2,3}$ Martine Hébert, Ph.D., ${ }^{5}$ Isabelle Ouellet-Morin, Ph.D., ${ }^{6}$ Frank Vitaro, Ph.D., ${ }^{7}$ Richard Tremblay, Ph.D., ${ }^{8,9}$ Sylvana M. Côté, Ph.D., ${ }^{3,10}$ Massimiliano Orri, Ph.D., ${ }^{10} \&$ Marie-Claude Geoffroy, Ph.D. ${ }^{1,10}$

${ }^{1}$ Department of Educational and Counselling Psychology, McGill University, Montreal, Quebec, Canada

${ }^{2}$ CHU Ste-Justine Hospital Research Center, Montreal, Quebec, Canada

${ }^{3}$ Department of Social and Preventive Medicine, University of Montreal, Quebec, Canada

${ }^{4}$ Department of Psychology, Concordia University, Montreal, Quebec, Canada

${ }^{5}$ Department of Sexology, Université du Québec à Montréal, Montreal, Quebec, Canada

${ }^{6}$ School of Criminology, University of Montreal \& the Montreal Mental Health University Institute, Montreal, Quebec, Canada

${ }^{7}$ School of Psycho-Education, University of Montreal, Montreal, Quebec, Canada

${ }^{8}$ Department of Pediatrics and Psychology, University of Montreal, Montreal, Quebec, Canada

${ }^{9}$ School of Public Health, Physiotherapy \& Sport Science, University College Dublin, Dublin, Ireland

${ }^{10}$ McGill Group for Suicide Studies, Douglas Mental Health University Institute, Department of Psychiatry, McGill University, Montreal, Quebec, Canada

Corresponding author: Marie-Claude Geoffroy, Department of Educational and Counselling Psychology, McGill University, 3700 McTavish Street, H3A 1Y2, Montreal, Quebec, Canada marieclaude.geoffroy@ mcgill.ca, 514-398-2817

Word Count: 2996 
medRxiv preprint doi: https://doi.org/10.1101/2022.01.06.22268834; this version posted January 6, 2022. The copyright holder for this preprint (which was not certified by peer review) is the author/funder, who has granted medRxiv a license to display the preprint in perpetuity.

It is made available under a CC-BY-NC-ND 4.0 International license .

Author Contributions: Ms Bouchard and Dr. Geoffroy had full access to all the data in the study and take responsibility for the integrity of the data and the accuracy of the data analysis.

Concept and design: Bouchard, Langevin, Orri, Vergunst, Côté, Geoffroy,

Acquisition, analysis, or interpretation of data: All authors

Drafting of the manuscript: Bouchard, Langevin, Geoffroy

Critical revision of the manuscript for important intellectual content: All authors

Statistical analysis: Bouchard, Vergunst, Orri, Domond, Geoffroy

Obtained funding: Côté, Tremblay, Vitaro

Administrative, technical, or material support: Bouchard, Tremblay, Geoffroy

Supervision: Geoffroy, Langevin

Conflict of Interest Disclosures: Ms. Bouchard received a master's award from the Social Sciences and Humanities Research Council, as well as the Quebec Network on Suicide, Mood disorders, and Related Disorders. Dr. Vergunst is funded by the Canadian Institute of Health Research (CIHR) and Fonds de Recherche du Quebec-Santé (FRQS) postdoctoral fellowship. Drs. Ouellet Morin (Tier 2), Hébert (Tier 1) and Geoffroy (Tier 2) hold a Canada Research Chair. No other disclosures were reported.

Funding/Support: Data collection for this study was funded by grants from the CIHR, SSHRC, FRQSC and FRQ-S.

Role of the Funder/Sponsor: The funder had no role in the design and conduct of the study; collection, management, analysis, and interpretation of the data; preparation, review or approval of the manuscript; and decision to submit the manuscript for publication.

\section{Additional Information:}


medRxiv preprint doi: https://doi.org/10.1101/2022.01.06.22268834; this version posted January 6, 2022. The copyright holder for this preprint

(which was not certified by peer review) is the author/funder, who has granted medRxiv a license to display the preprint in perpetuity.

It is made available under a CC-BY-NC-ND 4.0 International license.

\section{$\underline{\text { Key Points }}$}

Question: Is child sexual abuse associated with lower mid-life employment earnings?

Findings: In a large population-based cohort $(n=3,020)$, children exposed to sexual abuse had lower annual employment earnings from age 33-37 years than children nonexposed, after adjustment for childhood socioeconomic circumstances. These differences were more pronounced for individuals with official Child Protection Service reports compared to those with retrospective reports, and for individuals who experienced more severe forms of sexual abuse (i.e., penetration, intra-familial).

Meaning: Children exposed to sexual abuse are at risk of poor socioeconomic outcomes in midadulthood; interventions and support to improve long-term economic participation should be considered. 
medRxiv preprint doi: https://doi.org/10.1101/2022.01.06.22268834; this version posted January 6, 2022. The copyright holder for this preprint (which was not certified by peer review) is the author/funder, who has granted medRxiv a license to display the preprint in perpetuity.

It is made available under a CC-BY-NC-ND 4.0 International license .

\begin{abstract}
$\underline{\text { Abstract }}$
Importance: Individuals who have been sexually abused are at a greater risk for poor health, but associations with economic outcomes in mid-life have been overlooked.

Objectives: We investigated associations between child sexual abuse ( $\leq 18$ years) and economic outcomes at 33-37 years, while considering type of report (official/retrospective) and characteristics of abuse (type, severity, and chronicity).
\end{abstract}

Design: This cohort study used data collected for the Quebec Longitudinal Study of Kindergarten Children.

Setting: The Quebec Longitudinal Study of Kindergarten Children is a population-based sample.

Participants: Participants were 3,020 boys and girls attending kindergarten in the Canadian Province of Quebec in 1986/88 and followed up until 2017.

Main outcome/Measures: Child sexual abuse (0-18 years old) was assessed using both retrospective self-report questionnaires and objective reports (notification to Child Protection Services). Information on employment earnings was obtained from government tax return records. Tobit regressions were used to test associations of sexual abuse with earnings adjusting for sex and family socioeconomic background.

Results: Of the 3,020 participants 1,320 [43.7\%] self-reported no sexual abuse, 1,340 [44.3\%] had no official report but were missing on the retrospective questionnaire, 340 [11.3\%] reported retrospective sexual abuse, and 20 [0.7\%] had official report. In the fully adjusted model, individuals who retrospectively reported being sexually abused earned US\$4,031 (CI=-7,134 to -931) less per year at age 33-37 years, while those with official reports earned US\$16,042 (CI=-27,465 to -4,618) less, compared to participants who were not abused. Among individuals with retrospectively reported abuse, 
medRxiv preprint doi: https://doi.org/10.1101/2022.01.06.22268834; this version posted January 6, 2022. The copyright holder for this preprint (which was not certified by peer review) is the author/funder, who has granted medRxiv a license to display the preprint in perpetuity. It is made available under a CC-BY-NC-ND 4.0 International license.

those who experienced intra-familial abuse earned US\$4,696 (CI=-9,316 to -75) less than individuals who experienced extra-familial abuse, while participants who experienced penetration earned US\$6,188 (CI=-12,248 to -129) less than those who experienced non-contact abuse.

Conclusion and Relevance: Child sexual abuse puts individuals at risk for lasting reductions in employment earnings in adulthood. Early identification and support for sexual abuse victims could help reduce the economic gap and improve long-term outcomes. 
medRxiv preprint doi: https://doi.org/10.1101/2022.01.06.22268834; this version posted January 6, 2022. The copyright holder for this preprint (which was not certified by peer review) is the author/funder, who has granted medRxiv a license to display the preprint in perpetuity.

It is made available under a CC-BY-NC-ND 4.0 International license .

\section{Introduction}

Child sexual abuse is a worldwide concern. Its prevalence ranges between 8 to $31 \%$ for women and 3 to $17 \%$ for men, ${ }^{1}$ but only a minority of sexually abused children come to the attention of Child Protection Services (CPS). ${ }^{2}$ Child sexual abuse can have devasting consequences on mental (e.g., depression, suicide attempts) and physical health (e.g., obesity, cardiovascular diseases) which may persist over the life course, ${ }^{2-6}$ and even the next generations. ${ }^{7,8}$ Though, less is known on the consequences of child sexual abuse on personal earnings across early adulthood and into middle-age. Clarifying the extent of these costs for individuals and society could strengthen the case for early intervention programs aimed at supporting long-term economic participation among sexual abuse victims.

To date, much of the evidence on the putative risk of sexual abuse on socioeconomic outcomes comes from studies of young adult populations. These studies reported that individuals who have been sexually abused as children had lower educational achievement, ${ }^{9,10}$ were more likely to be unemployed, ${ }^{11}$ and to benefit from welfare support in early adulthood, ${ }^{12}$ (18-25 years) even after accounting for childhood socioeconomic circumstances (e.g., parental earnings). Such findings raise concerns that child sexual abuse can negatively influence socioeconomic status later in life. However, to the best of our knowledge only four longitudinal studies have investigated associations between child sexual abuse and socioeconomic indicators by mid-adulthood. Three of these studies relied on self-report measures of abuse, ${ }^{10,13,14}$ and only one examined sexual abuse via official records, finding that those with official records of sexual abuse reported earning around US\$11,000 less per year. ${ }^{15}$ Additionally, the studies also relied on self-report measures of socioeconomic conditions that are likely to be biased (e.g., higher attrition rates among participants with lower socioeconomic status, misreporting). ${ }^{16}$ Moreover, child sexual abuse may vary in severity, and it is unknown if more severe abuse puts individuals at-risk for poor economic outcomes. To our knowledge, there are no studies 
medRxiv preprint doi: https://doi.org/10.1101/2022.01.06.22268834; this version posted January 6, 2022. The copyright holder for this preprint (which was not certified by peer review) is the author/funder, who has granted medRxiv a license to display the preprint in perpetuity.

It is made available under a CC-BY-NC-ND 4.0 International license .

examining the risks of child sexual abuse using both retrospective and official reports on personal earnings using official government tax records.

\section{Aims}

Drawing on a population-based cohort, this study examined the association between child sexual abuse and participants' employment earnings at 33-37 years old obtained from tax return records. We investigated association for both sexual abuse officially reported to CPS (0-18 years old), and sexual abuse self-reported retrospectively at age 22 years. Additionally, given that individuals who have reported more severe forms of sexual abuse (e.g., involving penetration) might experience worse outcomes in adulthood, ${ }^{17}$ we investigated whether the characteristics of the sexual abuse in terms of type (i.e., intra vs. extra-familial), severity (i.e., involving penetration vs. touching/non-contact) and chronicity (i.e., one episode vs. more than one abusive episode) were associated with employment earnings among individuals with self-reported abuse. Furthermore, we estimated the risk of child sexual abuse on lost employment earnings over a 40-year working career. It is crucial to document the breadth of the consequences of child sexual abuse including on socioeconomic outcomes, especially given that poor socioeconomic status is a well-known risk factor for health and intergenerational continuity of sexual abuse. ${ }^{7}$

\section{Methods}

\section{Participants}

The Quebec Longitudinal Study of Kindergarten Children (QLSKC) is a longitudinal cohort of 3,020 boys and girls recruited while attending kindergarten in French-speaking schools in the Province of Quebec during the 1986-87 and 1987-88 school years and followed-up until $2017 .{ }^{18}$ Of these 3,020 children, 2,000 children (1,001 boys and 999 girls) were representative of Quebec kindergarteners (random sample) and 1,020 children (600 boys and 420 girls) were oversampled for disruptive 
medRxiv preprint doi: https://doi.org/10.1101/2022.01.06.22268834; this version posted January 6, 2022. The copyright holder for this preprint (which was not certified by peer review) is the author/funder, who has granted medRxiv a license to display the preprint in perpetuity.

It is made available under a CC-BY-NC-ND 4.0 International license .

behaviors, defined as scores $\geq 80$ th percentile on the disruptive behaviors scale from the Social

Behavior Questionnaire. ${ }^{19}$ Ethics approval was obtained from the University of Montreal Ethics Board and Statistics Canada. Written informed consent was obtained at each assessment.

\section{Official report of child sexual abuse}

When participants reached 18 years of age, their official reports of child sexual abuse were extracted from the Quebec Ministry of Health and CPS via the Director of Youth Protection. For the purposes of this study, we included all notifications to CPS for sexual abuse regardless of substantiation ( $n=20)$. Notifications for sexual abuse include (1) a situation in which the child is subjected to gestures of a sexual nature by the child's parents or another person, with or without physical contact, and the child's parents fail to take the necessary steps to put an end to the situation and (2) a situation in which the child runs a serious risk of being subjected to gestures of a sexual nature by the child's parents or another person, with or without physical contact, and the child's parents fail to take the necessary steps to put an end to the situation. ${ }^{20}$

\section{Retrospective report of child sexual abuse}

At 22 years old, participants retrospectively completed five questions adapted from the Adverse Childhood Experiences Questionnaire $e^{21,22}$ and from the Sexually Victimized Children Questionnaire ${ }^{23}$ assessing sexual abuse before the age of 18 years. They were asked whether they had experienced unwanted sexual acts in the form of exhibitionism, sexual fondling/touching, penetration or attempted penetration by bribe, threat or force, or by drugs and/or alcohol (e.g., "Did someone show you their sexual parts or force you to show them your sexual parts when did you did not want too?”). When participants responded "yes" to any of the questions, they were asked about the nature of their relationship to the perpetrator (i.e., within the family, within the extended family, acquaintance from school, or stranger), and frequency of the abuse (e.g., one time or more). We created three variables indicating the characteristics of sexual abuse according to the (i) type of abuse: intra-familial (e.g., parents, siblings, relative) vs extra-familial perpetrator (e.g., stranger, acquaintance from school), (ii) 
medRxiv preprint doi: https://doi.org/10.1101/2022.01.06.22268834; this version posted January 6, 2022. The copyright holder for this preprint (which was not certified by peer review) is the author/funder, who has granted medRxiv a license to display the preprint in perpetuity.

It is made available under a CC-BY-NC-ND 4.0 International license .

severity: penetration/attempted penetration, sexual fondling/touching, non-contact (e.g., exhibitionism, voyeurism), and (iii) chronicity: one abusive episode vs. more than one abusive episode.

\section{Adult employment earnings}

Employment earnings were obtained annually from 18-37 years old (1998-2017) from federal government tax returns (Statistics Canada) and linked to the QLSKC cohort. ${ }^{24}$ It includes pretax wages, salaries, and commissions, excluding income from capital gains. To account for random yearly variations, the mean of the 5 most recent tax return records were used (when participants were 33-37 years of age). For ease of comparability, all financial data was converted to US dollars prior to analysis using the current purchase power parity rate (CAD1=USD0.83).

\section{Childhood socioeconomic characteristics}

Childhood socioeconomic characteristics known for their associations with child sexual abuse $^{12,25,26}$ later socioeconomic outcomes ${ }^{27}$ were controlled for in all analyses. Namely, parental earnings, years of education, age at child's birth (average of mother and father) and family composition (single vs. two parents), in addition to child's sex and disruptive sample membership. Information on parental earnings were obtained when children were 2-7 years old (1982-1987) from government tax return records, while other characteristics were collected via a questionnaire administered to the mother when participants were aged 6 years.

\section{Statistical Analyses}

We investigated the prevalence of sexual abuse and childhood socioeconomic correlates of child sexual abuse in the whole sample $(n=3,020)$, considering both official and retrospective sexual abuse in four non-overlapping categories: (1) no official and retrospective reports; (2) no official report and missing on retrospective report; (3) retrospective report and no official report (4) official report, including seven individuals with concurrent retrospective report, and characteristics of retrospective report (type, severity, and chronicity). Next, we used tobit regressions to investigate the associations 
medRxiv preprint doi: https://doi.org/10.1101/2022.01.06.22268834; this version posted January 6, 2022. The copyright holder for this preprint (which was not certified by peer review) is the author/funder, who has granted medRxiv a license to display the preprint in perpetuity.

It is made available under a CC-BY-NC-ND 4.0 International license .

between child sexual abuse and average employment earnings in the last 5 years (33-37 years) left censured at $\$ 0$. To reduce the effect of extreme outliers, income scores at or above the $99^{\text {th }}$ percentile were winsorized. To examine the extent to which participant sex, disruptive sample membership, and childhood socioeconomic characteristics explain the association between child sexual abuse and adulthood earnings, we fitted three models with different adjustment levels: (1) unadjusted, (2) adjusted for sex, and (3) adjusted for childhood characteristics described above (disruptive sample membership was controlled for in all models).

Missing values on childhood socioeconomic characteristics range from $0 \%$ (sex) to $30 \%$ (family composition). To avoid losing participants due to missing information on confounders, we imputed missing values using multiple imputation by chained equations; ${ }^{28}$ analyses were conducted across 50 pooled imputed datasets.

To estimate the long-term economic consequence of child sexual abuse, we estimated the loss of individual earnings over a 40-year work career:

$$
\text { Economic impact }=\sum_{t=1}^{40} \frac{\beta}{1.03}=23.8 \times \beta
$$

Where $B$ is the estimate from the fully adjusted model, while assuming a discount rate of $3 \% .{ }^{29}$ This indicates the lifetime loss of earnings attributable to sexual abuse, independently from background socioeconomic characteristics.

All analyses were repeated in regard to the type of abuse, severity, and chronicity of abuse as exposure among the individuals with retrospective report of abuse.

\section{Results}

Frequencies of child sexual abuse and characteristics of abuse are presented in Table 1. Of the 3,020 participants 1,320 [43.7\%] self-reported no sexual abuse, 1,340 [44.3\%] had no official report but were missing on the retrospective questionnaire, 340 [11.3\%] reported retrospective sexual 
medRxiv preprint doi: https://doi.org/10.1101/2022.01.06.22268834; this version posted January 6, 2022. The copyright holder for this preprint (which was not certified by peer review) is the author/funder, who has granted medRxiv a license to display the preprint in perpetuity. It is made available under a CC-BY-NC-ND 4.0 International license .

abuse, and 20 [0.7\%] had official report. While excluding the 1,340 participants with missing information, $25.7 \%$ of the sample reported child sexual abuse.

With regards to characteristics of abuse, more participants self-reported extra-familial (61.4\%), penetration or attempted penetration (40.3\%) and fondling (38.0\%) and were abused on one occasion (82.4\%). Participants who were sexually abused or exposed to the most severe forms of abuse were more likely to come from an underprivileged family in terms of parental education and earnings than those who were not sexually abused (eTable 1 and eTable 2).

Descriptive statistics for the association between child sexual abuse and employment earnings from 18-37 years are reported in Figure 1 and Figure 2. The average of the last 5 available years (ages 33-37) was US\$32,800 ( $S D=24,840)$. Participants who experienced sexual abuse earned less than those who did not experience sexual abuse, with official reports being associated with the lowest earnings across follow-up. Analyses controlling for sex, disruptive behaviour and childhood socioeconomic characteristics including parental earnings are shown in Table 2. Compared to those who did not experience child sexual abuse, individuals who retrospectively reported sexual abuse earned US $\$ 4,031$ $(C I=-7,134 ;-931)$ less, while those with official reports earned US\$16,042 (CI =-27,465;-4,618) less. Those missing the retrospective report, but with no official report, also had lower annual earnings, but this difference was not statistically significant US\$-1,906 (CI =-3,912;98). Over a 40-year working career, the loss of personal earnings attributable to sexual abuse was US\$95,956 (CI =-169,740; $22,171)$ for retrospectively reported abuse and US $\$ 381,800(-653,709 ;-109,946)$ for officially reported abuse. This estimates account for all confounders used in the fully adjusted model, and a 3\% annual discount rate.

As illustrated in Figures 2a and 2b, participants who experienced intra-familial abuse or penetration/attempted penetration earned less from 18-37 years old than those who experienced extrafamilial abuse or non-contact sexual abuse, respectively (no difference was observed for chronicity of abuse, see Figure 2c). Fully adjusted analyses revealed that compared to those who experienced extra- 
medRxiv preprint doi: https://doi.org/10.1101/2022.01.06.22268834; this version posted January 6, 2022. The copyright holder for this preprint (which was not certified by peer review) is the author/funder, who has granted medRxiv a license to display the preprint in perpetuity.

It is made available under a CC-BY-NC-ND 4.0 International license .

familial abuse, individuals who experienced intra-familial abuse earned US\$4,696 (CI=-9,316;-75) less. Individuals who experienced more severe sexual abuse (i.e., penetration) earned US\$6,188 (CI=12,248;-129) less than those who experienced non-contact sexual abuse. No significant difference in earnings was observed between participants who experienced sexual touching vs. non-contact sexual abuse and those with one episode vs. multiple episodes of sexual abuse (Table 3). Results based on complete cases did not substantively differ from the main results (eTable3 and eTable4). Across a 40year working career, the loss of personal earnings attributed to severity of sexual abuse (e.g., penetration) was US\$147,309 (CI = -291,532;-3,086). The loss of personal earnings attributed to intrafamilial abuse was US\$111,804 (CI = -221,741;-1867).

\section{Discussion}

To our knowledge, this is the first longitudinal study to investigate associations between child sexual abuse (retrospective and official reports) and long-term employment earnings by mid-life. Using employment earning data obtained from government tax return records linked to over 3000 participants from the community, we found that individuals who experienced child sexual abuse endured poor longterm economic outcomes. To illustrate, individuals who retrospectively reported being exposed to penetrative and intra-familial sexual abuse had over US\$100,000 lower annual earnings than nonabused children across a 40-year working career, while those who were notified to CPS for sexual abuse had over US\$300,000 lower annual earnings than non-abused children across their careers. Our estimates were robust to adjustment for a range of childhood confounders including parental earnings gathered from tax records.

\section{Methodological considerations}

Our study has several strengths. First, we relied on a large population-based cohort followed for almost four decades. Second, we used both retrospective and official CPS records to assess child sexual abuse. By using official records, we obtained a more objective rating of child sexual abuse and avoid many of the reporting biases (e.g., desirability or memory biases) found in retrospective data. ${ }^{30,31}$ 
medRxiv preprint doi: https://doi.org/10.1101/2022.01.06.22268834; this version posted January 6, 2022. The copyright holder for this preprint (which was not certified by peer review) is the author/funder, who has granted medRxiv a license to display the preprint in perpetuity. It is made available under a CC-BY-NC-ND 4.0 International license .

Alternatively, by using retrospective reports of child sexual abuse, it allows us to anonymously collect large amounts of sensitive data, ${ }^{30}$ while capturing cases that have gone unreported to $\mathrm{CPS} .{ }^{32}$ Indeed, within the Province of Quebec, only 0.48 incidents for every 1,000 children living in the province were reported to CPS. ${ }^{33}$ Third, for those with retrospective reports, we had detailed information on the characteristics of sexual abuse allowing us to examine how type, severity and chronicity influence employment earnings. Fourth, we used objective measures of employment earnings (i.e., government tax returns). Finally, we controlled for key childhood confounders including parental earnings which were also obtained from tax records.

However, our findings also need to be interpreted in light of methodological limitations. First, as about one-third of participants did not answer the retrospective questionnaire on sexual abuse, we might have underestimated the true association between retrospectively reported sexual abuse and employment earnings. But it is worth noting that our main analyses did not reveal differences between participants who were missing on the retrospective questionnaire and those who were not abused in terms of employment earnings. Second, despite our large sample, only 20 participants were identified by CPS for sexual abuse, increasing confidence intervals around estimates, and preventing us from completing detailed analyses regarding characteristics of the abuse and the victim (e.g., sex). Therefore, a replication of our study with an at-risk sample for sexual abuse is recommended. Third, we did not control for other forms of child maltreatment (e.g., physical abuse, neglect), hence we do not know whether the earning difference is solely due to child sexual abuse or whether it could be better explained by the cumulative risk of different forms of abuse and childhood adversity. Fourth, we did not control for child (before the abuse) and parental psychopathology, which could increase sexual abuse risk and lower long-term earnings. Finally, we were unable to examine the differential risk by sex due to a lower number of victims among men.

Our results concur with some previous studies, ${ }^{10,14}$ but not others. For example, a study based on the Ontario Child Health Study $(\mathrm{N}=1,454)$ failed to report an association between child sexual 
medRxiv preprint doi: https://doi.org/10.1101/2022.01.06.22268834; this version posted January 6, 2022. The copyright holder for this preprint (which was not certified by peer review) is the author/funder, who has granted medRxiv a license to display the preprint in perpetuity. It is made available under a CC-BY-NC-ND 4.0 International license .

abuse, assessed retrospectively with one self-reported item and self-reported earnings among employed adults at 21-35 years. ${ }^{13}$ In our study, although there was an overall association between retrospectively reported child sexual abuse and employment earnings, additional analyses revealed that associations with employment earnings were seen only for the most severe forms of sexual abuse, namely penetration, intra-familial abuse, and official reports, which could not be tested in the previous study using a single broad self-reported item to document abuse. To illustrate, participants abused by a family member earned over US\$4,000 less between the ages of 33-37 per year than those abused by someone outside of their family. Such findings are in line with a prior study within this cohort showing that suicide attempt risk at 22 years old was 5 times higher for those sexually abused by a family member compared to those abused by someone outside the family. ${ }^{34}$

In our study, the largest earning differences was observed for children with official reports of sexual abuse, with mean individual annual earnings over US\$16,000 less (between ages 33-37 years old) compared to their non-abused counterparts. As only 20 participants had official reports of sexual abuse, these results should be interpreted with caution. Nevertheless, another prospective cohort of 807 males and females with official records of sexual abuse and self-reported socioeconomic outcomes found that sexual abuse was associated with an income gap of US\$8,000 at age 41, and that abused individuals were less likely to be in a skilled job, employed, own stocks, a vehicle or a home. ${ }^{15}$ Typically, children who are reported to CPS for sexual abuse represent the most severe instances of sexual abuse ${ }^{35}$ which often arise in combination with other forms of abuse (e.g., neglect, physical abuse) and childhood adversity. ${ }^{33,36}$

As most prior studies, associations between sexual abuse and personal earnings were robust to adjustment of key confounding factors, including parental household earnings. However, in an article using data from the Christchurch Health and Development Study, ${ }^{12}$ the association between child sexual abuse and gross income was lost after adjustment for childhood factors.

\section{Potential Underlying Mechanisms}


medRxiv preprint doi: https://doi.org/10.1101/2022.01.06.22268834; this version posted January 6, 2022. The copyright holder for this preprint (which was not certified by peer review) is the author/funder, who has granted medRxiv a license to display the preprint in perpetuity.

It is made available under a CC-BY-NC-ND 4.0 International license.

Future studies are needed to replicate our findings but also to elucidate intermediary pathways. Deficits in cognitive abilities and educational attainments, ${ }^{37}$ poor physical (e.g., obesity, ${ }^{4}$ gastrointestinal symptoms, ${ }^{38}$ headaches ${ }^{39}$ ) and mental health (e.g., impairing depression, ${ }^{6}$ anxiety, ${ }^{40}$ substance use problems, ${ }^{38}$ suicide attempts ${ }^{29}$ ) associated with child abuse could be potential mediating pathways. Of note, in the 1958 British Birth Cohort associations of retrospective report of child abuse and financial insecurity and income-related support at age 50 years were not mediated by cognitive abilities and mental health during adolescence. ${ }^{10}$

\section{Implications and conclusions}

Overall, our findings suggest that child sexual abuse may contribute to socioeconomic inequalities in mid-adulthood. Such inequalities were especially pronounced for the most severe forms of abuse (official reports to CPS, intra-familial abuse, and penetration). As earnings is a marker for healthy aging, ${ }^{41}$ longevity, ${ }^{42}$ and can protect against the intergenerational continuity of child sexual abuse and maltreatment ${ }^{43}$ helping victims of sexual abuse to maximise their economic potential would contribute to resilient functioning and yield important social and economic returns for individuals and potentially society. 
medRxiv preprint doi: https://doi.org/10.1101/2022.01.06.22268834; this version posted January 6, 2022. The copyright holder for this preprint (which was not certified by peer review) is the author/funder, who has granted medRxiv a license to display the preprint in perpetuity. It is made available under a CC-BY-NC-ND 4.0 International license .

1. $\quad$ Barth J, Bermetz L, Heim E, Trelle S, Tonia T. The current prevalence of child sexual abuse worldwide: a systematic review and meta-analysis. Int J Public Health. 2013;58(3):469-83. doi:10.1007/s00038-012-0426-1

2. Gilbert R, Widom CS, Browne K, Fergusson D, Webb E, Janson S. Burden and consequences of child maltreatment in high-income countries. Lancet. 2009;373(9657):68-81. doi:10.1016/s0140-6736(08)61706-7

3. Clark C, Caldwell T, Power C, Stansfeld SA. Does the influence of childhood adversity on psychopathology persist across the lifecourse? A 45-year prospective epidemiologic study. Ann Epidemiol. 2010;20(5):385-94. doi:10.1016/j.annepidem.2010.02.008

4. Power C, Pinto Pereira SM, Li L. Childhood Maltreatment and BMI Trajectories to Mid-Adult Life: Follow-Up to Age 50y in a British Birth Cohort. PLOS ONE. 2015;10(3):e0119985. doi:10.1371/journal.pone.0119985

5. Chen LP, Murad MH, Paras ML, et al. Sexual abuse and lifetime diagnosis of psychiatric disorders: systematic review and meta-analysis. Elsevier; 2010:618-629.

6. Putnam FW. Ten-year research update review: Child sexual abuse. Journal of the American Academy of Child \& Adolescent Psychiatry. 2003;42(3):269-278.

7. McCloskey LA, Bailey JA. The intergenerational transmission of risk for child sexual abuse. Journal of interpersonal violence. 2000;15(10):1019-1035.

8. Langevin R, Hébert M, Kern A. Maternal history of child sexual abuse and maladaptive outcomes in sexually abused children: the role of maternal mental health. Journal of interpersonal violence. 2021:08862605211013963.

9. $\quad$ Font SA, Maguire-Jack K. It's not "Just poverty": Educational, social, and economic functioning among young adults exposed to childhood neglect, abuse, and poverty. Child Abuse Negl. 2020;101:104356. doi:10.1016/j.chiabu.2020.104356

10. Pereira P, Li L, Power C. Child Maltreatment and Adult Living Standards at 50 Years. Pediatrics. 2017;139(1):e20161595. doi:10.1542/peds.2016-1595

11. Strathearn L, Giannotti M, Mills R, Kisely S, Najman J, Abajobir A. Long-term Cognitive, Psychological, and Health Outcomes Associated With Child Abuse and Neglect. Pediatrics. 2020;146(4)e20200438. doi:10.1542/peds.2020-0438

12. Fergusson DM, McLeod GFH, Horwood LJ. Childhood sexual abuse and adult developmental outcomes: Findings from a 30-year longitudinal study in New Zealand. Child Abuse \& Neglect. 2013;37(9):664-674. doi:10.1016/j.chiabu.2013.03.013

13. Tanaka M, Jamieson E, Georgiades K, Duku EK, Boyle MH, MacMillan HL. The association between childhood abuse and labor force outcomes in young adults: Results from the Ontario child health study. Journal of Aggression, Maltreatment \& Trauma. 2011;20(8):821-844.

14. Fahy AE, Stansfeld SA, Smuk M, et al. Longitudinal associations of experiences of adversity and socioeconomic disadvantage during childhood with labour force participation and exit in later adulthood. Soc Sci Med. 2017;183:80-87. doi:10.1016/j.socscimed.2017.04.023

15. Currie J, Widom CS. Long-term consequences of child abuse and neglect on adult economic well-being. Child Maltreat. 2010;15(2):111-120. doi:10.1177/1077559509355316

16. Vergunst F, Tremblay RE, Nagin D, et al. Association Between Childhood Behaviors and Adult Employment Earnings in Canada. JAMA Psychiatry. 2019;76(10):1044-1051.

doi:10.1001/jamapsychiatry.2019.1326

17. Spataro J, Mullen PE, Burgess PM, Wells DL, Moss SA. Impact of child sexual abuse on mental health: prospective study in males and females. The British Journal of Psychiatry. 2004;184(5):416-421.

18. Rouquette A, Côté SM, Pryor LE, Carbonneau R, Vitaro F, Tremblay RE. Cohort Profile: The Quebec Longitudinal Study of Kindergarten Children (QLSKC). International Journal of Epidemiology. 2012;43(1):23-33. doi:10.1093/ije/dys177 
medRxiv preprint doi: https://doi.org/10.1101/2022.01.06.22268834; this version posted January 6,2022 . The copyright holder for this preprint (which was not certified by peer review) is the author/funder, who has granted medRxiv a license to display the preprint in perpetuity. It is made available under a CC-BY-NC-ND 4.0 International license .

19. Tremblay RE, Loeber R, Gagnon C, Charlebois P, Larivée S, LeBlanc M. Disruptive boys with stable and unstable high fighting behavior patterns during junior elementary school. $J$ Abnorm Child Psychol. 1991;19(3):285-300. doi:10.1007/bf00911232

20. Youth Protection Act, 38 Government of Quebec 18-19 (2021).

21. Felitti VJ, Anda RF, Nordenberg D, et al. Relationship of childhood abuse and household dysfunction to many of the leading causes of death in adults. The Adverse Childhood Experiences (ACE) Study. Am J Prev Med. 1998;14(4):245-58. doi:10.1016/s07493797(98)00017-8

22. Dube SR, Felitti VJ, Dong M, Chapman DP, Giles WH, Anda RF. Childhood abuse, neglect, and household dysfunction and the risk of illicit drug use: the adverse childhood experiences study. Pediatrics. 2003;111(3):564-72. doi:10.1542/peds.111.3.564

23. Finkelhor D. Sexually victimized children. Free Press; 1979:xii, 228 p.

24. Findlay LC, Beasley E, Park J, et al. Longitudinal child data: what can be gained by linking administrative data and cohort data? International Journal of Population Data Science. 2018;3(1)

25. Hecht DB, Hansen DJ. The environment of child maltreatment: contextual factors and the development of psychopathology. Aggression and Violent Behavior. 2001;6(5):433-457. doi:https://doi.org/10.1016/S1359-1789(00)00015-X

26. Collin-Vézina D, Daigneault I, Hébert M. Lessons learned from child sexual abuse research: prevalence, outcomes, and preventive strategies. Child and Adolescent Psychiatry and Mental Health. 2013;7(1):22. doi:10.1186/1753-2000-7-22

27. Power C, Matthews S. Origins of health inequalities in a national population sample. Lancet. 1997;350(9091):1584-9. doi:10.1016/s0140-6736(97)07474-6

28. Azur MJ, Stuart EA, Frangakis C, Leaf PJ. Multiple imputation by chained equations: what is it and how does it work? Int J Methods Psychiatr Res. 2011;20(1):40-9. doi:10.1002/mpr.329

29. Orri M, Vergunst F, Turecki G, et al. Long-term economic and social outcomes of youth suicide attempts. The British Journal of Psychiatry. 2021:1-7. doi:10.1192/bjp.2021.133

30. Hardt J, Rutter M. Validity of adult retrospective reports of adverse childhood experiences: review of the evidence. Journal of Child Psychology and Psychiatry. 2004;45(2):260-273. doi:10.1111/j.1469-7610.2004.00218.x

31. Gotlib IH, Joormann J. Cognition and depression: current status and future directions. Annual review of clinical psychology. 2010;6:285-312. doi:10.1146/annurev.clinpsy.121208.131305

32. Kendall-Tackett K, Becker-Blease K. The importance of retrospective findings in child maltreatment research. Child Abuse Negl. 2004;28(7):723-7. doi:10.1016/j.chiabu.2004.02.002

33. Hélie S, Collin-Vézina D, Turcotte D, Trocmé N, Girouard N. Étude d'incidence québécoise sur les situations évaluées en protection de la jeunesse en 2014 (ÉIQ-2014). Rapport Final. 2017:1-115.

34. Brezo J, Paris J, Vitaro F, Hebert M, Tremblay RE, Turecki G. Predicting suicide attempts in young adults with histories of childhood abuse. The British Journal of Psychiatry. 2008;193(2):134-139.

35. Ammerman RT. Methodological Issues in Child Maltreatment Research. In: Lutzker JR, ed. Handbook of Child Abuse Research and Treatment. Springer US; 1998:117-132.

36. Dong M, Anda RF, Dube SR, Giles WH, Felitti VJ. The relationship of exposure to childhood sexual abuse to other forms of abuse, neglect, and household dysfunction during childhood. Child Abuse \& Neglect. 2003;27(6):625-639. doi:https://doi.org/10.1016/S01452134(03)00105-4

37. Geoffroy MC, Pinto Pereira S, Li L, Power C. Child Neglect and Maltreatment and Childhoodto-Adulthood Cognition and Mental Health in a Prospective Birth Cohort. J Am Acad Child Adolesc Psychiatry. 2016;55(1):33-40.e3. doi:10.1016/j.jaac.2015.10.012 
medRxiv preprint doi: https://doi.org/10.1101/2022.01.06.22268834; this version posted January 6, 2022. The copyright holder for this preprint (which was not certified by peer review) is the author/funder, who has granted medRxiv a license to display the preprint in perpetuity.

It is made available under a CC-BY-NC-ND 4.0 International license.

38. Nelson EC, Heath AC, Madden PA, et al. Association between self-reported childhood sexual abuse and adverse psychosocial outcomes: results from a twin study. Archives of general psychiatry. 2002;59(2):139-145.

39. Felitti VJ. Long-term medical consequences of incest, rape, and molestation. Southern medical journal. 1991;84(3):328-331.

40. Cougle JR, Timpano KR, Sachs-Ericsson N, Keough ME, Riccardi CJ. Examining the unique relationships between anxiety disorders and childhood physical and sexual abuse in the National Comorbidity Survey-Replication. Psychiatry research. 2010;177(1-2):150-155.

41. Guralnik JM, Kaplan GA. Predictors of healthy aging: prospective evidence from the Alameda County study. American journal of public health. 1989;79(6):703-708.

42. Marmot M. The influence of income on health: views of an epidemiologist. Health affairs. 2002;21(2):31-46.

43. MacMillan HL, Tanaka M, Duku E, Vaillancourt T, Boyle MH. Child physical and sexual abuse in a community sample of young adults: Results from the Ontario Child Health Study. Child Abuse \& Neglect. 2013;37(1):14-21. doi:https://doi.org/10.1016/j.chiabu.2012.06.005 
medRxiv preprint doi: https://doi.org/10.1101/2022.01.06.22268834; this version posted January 6, 2022. The copyright holder for this preprint (which was not certified by peer review) is the author/funder, who has granted medRxiv a license to display the preprint in perpetuity.

It is made available under a CC-BY-NC-ND 4.0 International license .

Table 1. Prevalence and characteristics of child sexual abuse

\begin{tabular}{ll} 
Child sexual abuse, No. (\%) & $\begin{array}{l}\text { Total } \\
n=3020\end{array}$ \\
\hline No sexual abuse & $1320(43.7)$ \\
Missing retrospective report, but no official report & $1340(44.3)$ \\
Retrospectively reported sexual abuse & $340(11.3)$ \\
Officially reported sexual abuse & $20(0.7)$ \\
Characteristics of retrospectively reported child sexual abuse, No. & $n=350$ \\
(\%) & \\
Type of abuse & $130(38.6)$ \\
\hline Intra-familial & $210(61.4)$ \\
\hline Extra-familial & \\
\hline Severity of abuse & $80(21.6)$ \\
\hline Non-contact & $130(38.0)$ \\
\hline Fondling & $140(40.3)$ \\
\hline Penetration or attempted penetration & $290(82.4)$ \\
\hline Chronicity & $60(17.6)$ \\
\hline One episode & \\
\hline More than one episode & \\
\hline Note. In accordance with Statistics Canada data protection requirements, displayed counts are rounded to base 10.
\end{tabular}


Table 2. Associations of officially and retrospectively reported child sexual abuse and adult employment earnings (33-37 years old); $n=3020$.

\section{Differences in employment earnings}

\begin{tabular}{lccc}
\hline & Unadjusted $^{\mathrm{b}}$ & Adjusted for sex $^{\mathrm{b}}$ & $\begin{array}{c}\text { Adjusted for family socioeconomic } \\
\text { characteristics }\end{array}$ \\
\hline b,c & $B[95 \% \mathrm{CI}]$ \\
\hline $\begin{array}{l}\text { Missing retrospective report, } \\
\text { but no official report }\end{array}$ & $\mathbf{- 3 , 1 8 1}[-5,236$ to $-1,127]$ & $B[95 \% \mathrm{CI}]$ & $-1,906$ \\
$\begin{array}{l}\text { Retrospectively reported sexual } \\
\text { abuse }\end{array}$ & $\mathbf{- 9 , 1 0 7}$ & {$[-6,157$ to $-2,107]$} & {$[-3,912$ to 98$]$} \\
Officially reported sexual & {$[-12,274$ to -5940$]$} & $\mathbf{- 5 , 5 1 3}$ & $\mathbf{- 4 , 0 3 1}$ \\
abuse & $\mathbf{- 2 6 , 9 9 3}$ & $-8,688$ to $-2,336]$ & $-\mathbf{- 2 3 , 2 8 4}, 134$ to -931$]$ \\
\hline
\end{tabular}

Note. ${ }^{\mathrm{a}}$ Based on imputed values $(\mathrm{N}=3020)$.

${ }^{\mathrm{b}}$ Estimates are beta coefficients from Tobit regression with $95 \%$ confidence intervals and indicate amounts in US dollars; all three models are adjusted for cohort membership (i.e., disruptive vs. representative sample)

${ }^{c}$ Adjusted for family characteristics including child sex, maternal and paternal education, parental earnings, parental mean age at childbirth, and family composition.

Reference category $=$ no abuse; significant differences at $p<0.05$ are bold. 
Table 3. Associations of characteristics of retrospectively reported child sexual abuse among victims of sexual abuse adult employment earnings; $n=350$.

\begin{tabular}{|c|c|c|c|}
\hline & \multicolumn{3}{|c|}{ Differences in employment earnings ${ }^{\mathrm{a}}$} \\
\hline & Unadjusted $^{\mathrm{b}}$ & Adjusted for sex ${ }^{b}$ & $\begin{array}{c}\text { Adjusted for family } \\
\text { socioeconomic characteristics }{ }^{\mathrm{b}, \mathrm{c}}\end{array}$ \\
\hline \multicolumn{4}{|l|}{ Type of abuse } \\
\hline $\begin{array}{l}\text { Intra-familial } \\
\text { (vs. extra familial abuse) }\end{array}$ & $\begin{array}{c}\mathbf{- 6 , 8 9 8} \\
{[-11,823 \text { to }-1,973]}\end{array}$ & $\begin{array}{c}\mathbf{- 6 , 4 1 6} \\
{[-11,275 \text { to }-1,557]}\end{array}$ & $\begin{array}{c}\mathbf{- 4 , 6 9 6} \\
{[-9,316 \text { to }-75]}\end{array}$ \\
\hline \multicolumn{4}{|l|}{ Severity of abuse } \\
\hline $\begin{array}{l}\text { Sexual touching } \\
\text { (vs. non-contact) }\end{array}$ & $\begin{array}{c}-5,603 \\
{[-11,934 \text { to } 726]}\end{array}$ & $\begin{array}{c}-4,502 \\
{[-10,813 \text { to } 1807]}\end{array}$ & $\begin{array}{c}3,515 \\
{[-9,456 \text { to } 2,427]}\end{array}$ \\
\hline $\begin{array}{l}\text { Penetration } \\
\text { (vs. non-contact) }\end{array}$ & $\begin{array}{c}\mathbf{- 1 0 , 4 7 1} \\
{[-16,764 \text { to }-4,179]}\end{array}$ & $\begin{array}{c}\mathbf{- 8 , 5 1 7} \\
{[-14,916 \text { to }-2,118]}\end{array}$ & $\begin{array}{c}\mathbf{- 6 , 1 8 8} \\
{[-12,248 \text { to }-129]}\end{array}$ \\
\hline \multicolumn{4}{|l|}{ Chronicity } \\
\hline $\begin{array}{l}\text { Multiple episodes } \\
\text { (vs. one episode) }\end{array}$ & $\begin{array}{c}-3,010 \\
{[-9,414 \text { to } 3,391]}\end{array}$ & $\begin{array}{c}-1,518 \\
{[-7,886 \text { to } 4,847]}\end{array}$ & $\begin{array}{c}-2,081 \\
{[-8,056 \text { to } 3,892]}\end{array}$ \\
\hline
\end{tabular}

Note. ${ }^{a}$ Based on imputed values $(\mathrm{N}=350)$.

${ }^{\mathrm{b}}$ Estimates are beta coefficients from Tobit regression with 95\% confidence intervals and indicate amounts in US dollars; all three models are adjusted for cohort membership (i.e., disruptive vs. representative cohorts).

${ }^{c}$ Adjusted for family characteristics including child sex, maternal and paternal education, parental earnings, parental mean age at childbirth, and family composition.

Significant differences at $p<0.05$ are bold. 
Figure 1. Descriptive statistics for employment earnings from 18 to 37 years old by sexual abuse group, $n=3,020^{\mathrm{a}}$

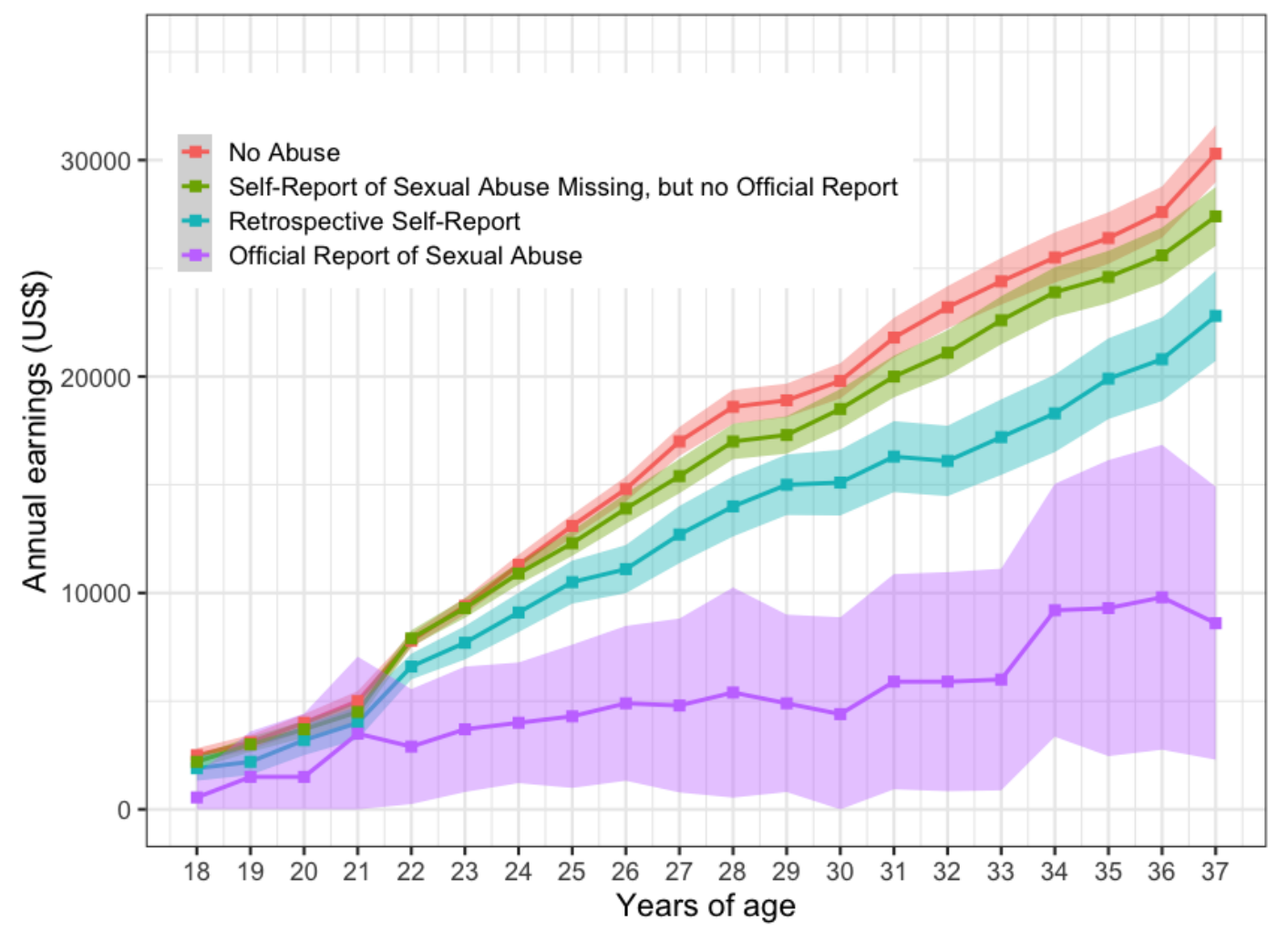

Note. ${ }^{\text {an }}$ accordance with Statistics Canada data protection requirements, displayed counts are rounded to base 10 and employment earnings were rounded to the closest 100 . 
medRxiv preprint doi: https://doi.org/10.1101/2022.01.06.22268834; this version posted January 6,2022 . The copyright holder for this preprint (which was not certified by peer review) is the author/funder, who has granted medRxiv a license to display the preprint in perpetuity.

It is made available under a CC-BY-NC-ND 4.0 International license.

Figure 2. Descriptive statistics for employment earnings from 18 to 37 years $(n=350)^{\mathrm{a}}$

A. Type of abuse

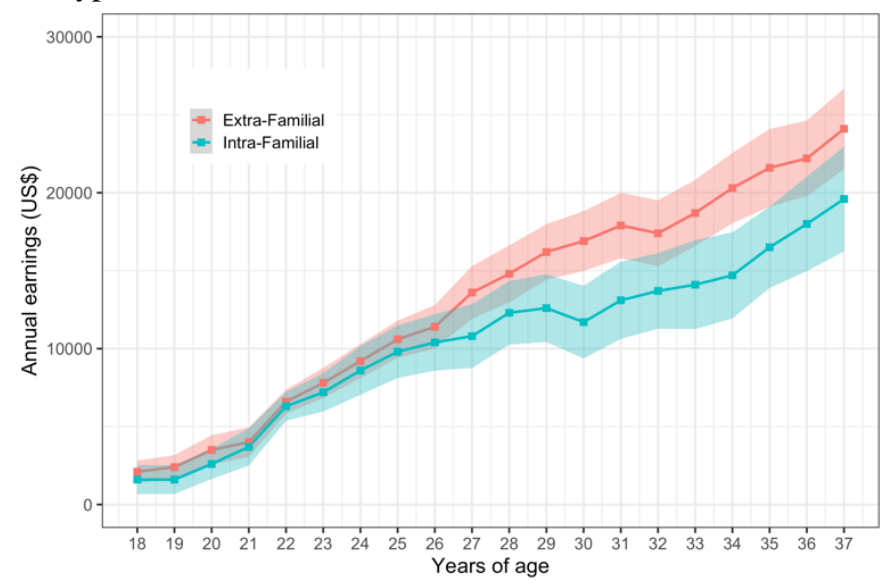

B. Severity of abuse

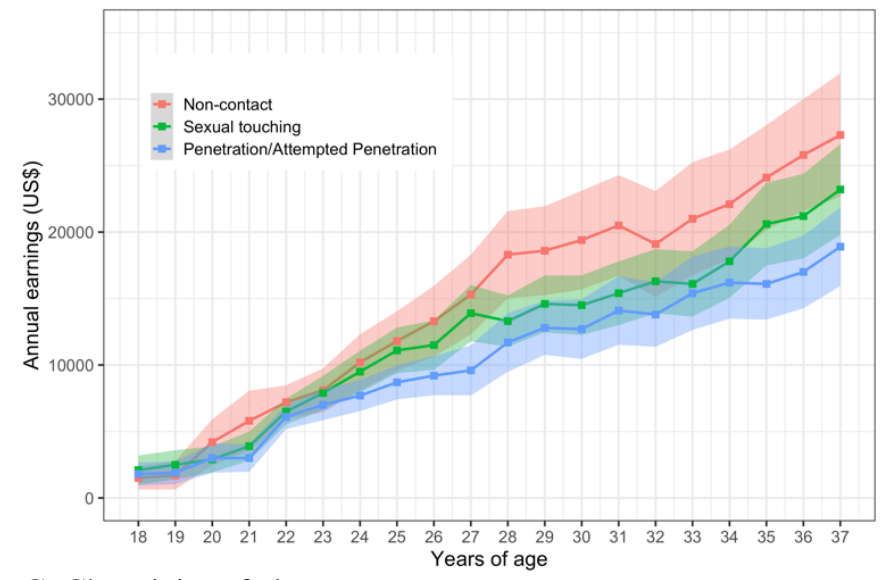

C. Chronicity of abuse

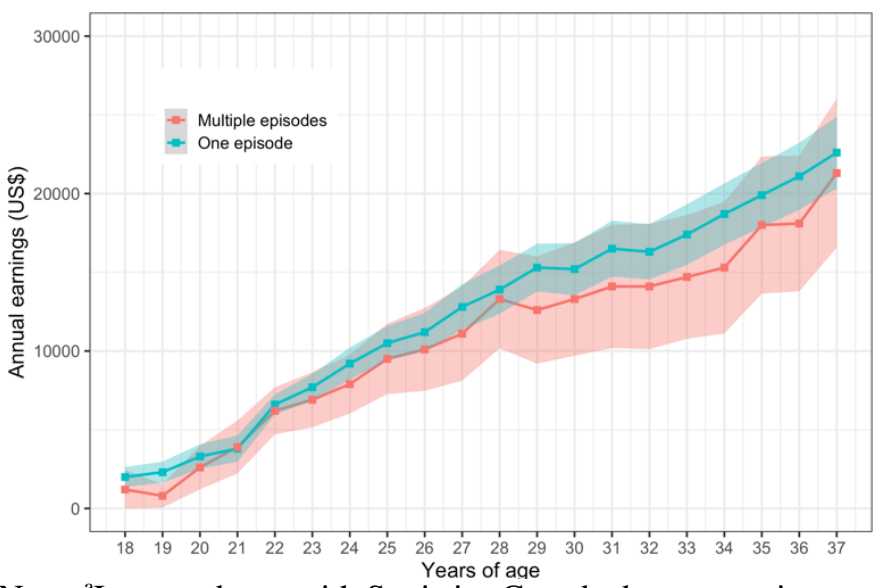

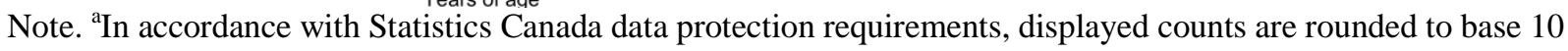
and employment earnings are rounded to the closest 100. 
eTable 1: Childhood socioeconomic characteristics by officially and retrospectively reported child sexual abuse

\begin{tabular}{|c|c|c|c|c|c|}
\hline & $\begin{array}{c}\text { No sexual abuse } \\
(n=1320)\end{array}$ & $\begin{array}{c}\text { Missing } \\
\text { retrospective } \\
\text { report, but no } \\
\text { official report } \\
(n=1340)\end{array}$ & $\begin{array}{c}\text { Officially reported } \\
\text { sexual abuse } \\
(n=20)\end{array}$ & $\begin{array}{c}\text { Retrospectively } \\
\text { reported sexual } \\
\text { abuse } \\
(n=340)\end{array}$ & $\begin{array}{l}\text { P-values for } \\
\text { group } \\
\text { differences }\end{array}$ \\
\hline & \multicolumn{5}{|c|}{$M(S D)$} \\
\hline \multicolumn{6}{|l|}{ Characteristics } \\
\hline Maternal education (years) & $12.17(2.60)$ & $11.21(2.62)$ & $10.15(2.08)$ & $11.84(2.42)$ & $<.001$ \\
\hline Father's education (years) & $12.29(3.34)$ & $11.29(3.38)$ & $9.62(3.16)$ & $12.22(3.48)$ & $<.001$ \\
\hline Parental mean age (years) & $27.93(4.24)$ & $27.69(4.62)$ & $26.37(5.13)$ & $27.93(4.39)$ & .236 \\
\hline Parental earnings in US dollars ${ }^{a}$ & $27,100(13970)$ & $22,600(15510)$ & $10,800(10190)$ & $23,400(14380)$ & $<.001$ \\
\hline Family composition (single parent); No.(\%) & $119(5.6)$ & $113(5.3)$ & $<5$ & $32(1.5)$ & .987 \\
\hline
\end{tabular}

Note. Based on a maximum N ranging from 2136 to 2998

${ }^{a}$ Rounded to the closest 100 according to Statistics Canada data protection regulations. 
eTable 2: Childhood socioeconomic characteristics by officially by characteristics of retrospectively reported child sexual abuse among victims of sexual abuse

\begin{tabular}{|c|c|c|c|c|c|c|c|c|c|c|c|}
\hline \multirow[t]{3}{*}{ Characteristics } & \multicolumn{3}{|c|}{ Type of abuse } & \multicolumn{4}{|c|}{ Severity of abuse } & \multicolumn{3}{|c|}{ Chronicity } & \multirow{2}{*}{ 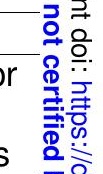 } \\
\hline & $\begin{array}{l}\text { Intra- } \\
\text { familial }\end{array}$ & Extra familial & $\begin{array}{l}\text { P-values for } \\
\text { group } \\
\text { differences }\end{array}$ & Non-Contact & $\begin{array}{l}\text { Sexual } \\
\text { touching }\end{array}$ & Penetration & $\begin{array}{l}\text { P-values for } \\
\text { group } \\
\text { differences }\end{array}$ & One episode & $\begin{array}{l}\text { More than } \\
\text { one episode }\end{array}$ & $\begin{array}{l}\text { P-values for } \\
\text { group } \\
\text { differences }\end{array}$ & \\
\hline & \multicolumn{10}{|c|}{$M(S D)$} & \multirow{6}{*}{ 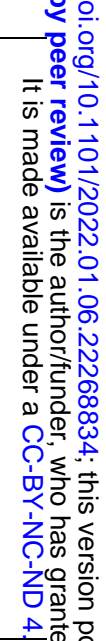 } \\
\hline $\begin{array}{l}\text { Maternal } \\
\text { education } \\
\text { (years) }\end{array}$ & $11.54(2.32)$ & $11.93(2.52)$ & .158 & $12.00(2.46)$ & $11.84(2.60)$ & $11.61(2.30)$ & .527 & $11.78(2.50)$ & $11.78(2.23)$ & .995 & \\
\hline $\begin{array}{l}\text { Father's } \\
\text { education } \\
\text { (years) }\end{array}$ & $11.48(3.04)$ & $12.06(3.70)$ & .007 & $12.64(3.53)$ & $12.46(3.70)$ & $11.67(3.22)$ & .110 & $12.20(3.52)$ & $12.10(3.43)$ & .842 & \\
\hline $\begin{array}{l}\text { Parental mean } \\
\text { age (years) }\end{array}$ & $27.55(4.38)$ & $28.13(4.51)$ & .248 & $28.33(4.04)$ & $27.66(4.21)$ & $27.92(4.90)$ & .586 & $27.84(4.42)$ & $28.25(4.67)$ & .510 & \\
\hline $\begin{array}{l}\text { Parental } \\
\text { earnings in US } \\
\text { dollars }^{a}\end{array}$ & $\begin{array}{l}21,300 \\
(13440)\end{array}$ & $\begin{array}{l}24,300 \\
(14,930)\end{array}$ & .057 & $\begin{array}{l}26,000 \\
(15,810)\end{array}$ & $\begin{array}{l}24,100 \\
(13,860)\end{array}$ & $\begin{array}{l}20,700 \\
(14,430)\end{array}$ & .022 & $\begin{array}{l}23,000 \\
(14,630)\end{array}$ & $\begin{array}{l}23,800 \\
(13,510)\end{array}$ & .670 & \\
\hline $\begin{array}{l}\text { Family } \\
\text { composition } \\
\text { (single parent); } \\
\text { No.(\%) }\end{array}$ & $13(39.4)$ & $20(60.6)$ & .847 & $6(18.2)$ & $11(33.3)$ & $16(48.5)$ & .712 & 27 (81.8) & $6(18.2)$ & . & \\
\hline $\begin{array}{l}\text { Note. Based on a m } \\
{ }^{\text {a }} \text { Rounded to the clo }\end{array}$ & $\begin{array}{l}\text { imum } N \text { ranging } f \\
\text { st } 100 \text { according }\end{array}$ & $\begin{array}{l}\text { om } 257 \text { to } 350 . \\
\text { Statistics Cana }\end{array}$ & ta protection & lations. & & & & & & & 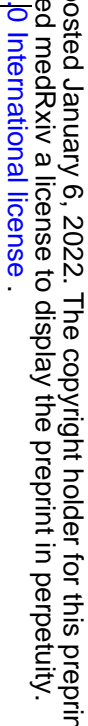 \\
\hline
\end{tabular}


eTable 3: Associations of child sexual abuse with adulthood employment earnings, completed case, $n=1740$. Differences in employment earnings ${ }^{\mathrm{a}}$

\begin{tabular}{|c|c|c|c|}
\hline & Unadjusted $^{\mathrm{b}}$ & Adjusted for sex ${ }^{b}$ & $\begin{array}{c}\text { Adjusted for family socioeconomic } \\
\text { characteristics }^{\text {b,c }}\end{array}$ \\
\hline \multicolumn{4}{|l|}{ Personal earnings } \\
\hline $\begin{array}{l}\text { Missing retrospective report, but no } \\
\text { official report }\end{array}$ & $-3,389[-5,458$ to $-1,323]$ & $\begin{array}{c}-\mathbf{4 , 3 8 2} \\
{[-6,412 \text { to }-2,350]}\end{array}$ & $\begin{array}{c}22.95 \\
{[-2,596 \text { to } 2,641]}\end{array}$ \\
\hline $\begin{array}{l}\text { Retrospectively reported sexual } \\
\text { abuse }\end{array}$ & $\begin{array}{c}-\mathbf{9}, \mathbf{1 4 8} \\
{[-12,339 \text { to }-5,960]}\end{array}$ & $\begin{array}{c}-5,375 \\
{[-8,568 \text { to }-2,181]}\end{array}$ & $\begin{array}{c}-3,375 \\
{[-7,385 \text { to } 634]}\end{array}$ \\
\hline Officially reported sexual abuse & $\begin{array}{c}\mathbf{- 2 6 , 9 7 8} \\
{[-38,970 \text { to }-14,985]}\end{array}$ & $\begin{array}{c}\mathbf{- 2 3 , 1 7 4} \\
{[-34,923 \text { to }-11,426]}\end{array}$ & $\begin{array}{c}-16,515 \\
{[-32,827 \text { to }-203]}\end{array}$ \\
\hline
\end{tabular}


eTable 4: Associations of characteristics of retrospectively reported child sexual abuse among victims of sexual abuse with adulthood employment earnings, completed case, $n=200$.

Differences in employment earnings in US dollars ${ }^{a}$

\begin{tabular}{|c|c|c|c|}
\hline & Unadjusted $^{\mathrm{D}}$ & Adjusted for sex ${ }^{\mathrm{b}}$ & $\begin{array}{c}\text { Adjusted for family socioeconomic } \\
\text { characteristics }^{\text {b,c }}\end{array}$ \\
\hline \multicolumn{4}{|l|}{ Type of abuse } \\
\hline $\begin{array}{l}\text { Intra-familial (vs. extra familial } \\
\text { abuse) }\end{array}$ & $\begin{array}{c}-6,886 \\
{[-11,781 \text { to }-1,992]}\end{array}$ & $\begin{array}{c}-6,297 \\
{[-11,117 \text { to }-1,478]}\end{array}$ & $\begin{array}{c}-1,823 \\
{[-10,539 \text { to } 2,010]}\end{array}$ \\
\hline \multicolumn{4}{|l|}{ Severity of abuse } \\
\hline $\begin{array}{l}\text { Sexual touching (vs. non-contact) } \\
\text { Penetration (vs. non-contact) }\end{array}$ & $\begin{array}{c}-5,719 \\
{[-11,881 \text { to } 710]} \\
-10,783 \\
{[-17,055 \text { to }-4,513]}\end{array}$ & $\begin{array}{c}-4,401 \\
{[-10,670 \text { to } 1,867]} \\
-\mathbf{8}, 587 \\
{[-14,960 \text { to }-1971]}\end{array}$ & $\begin{array}{c}-\mathbf{8}, \mathbf{4 7 9} \\
{[-16,506 \text { to }-450]} \\
\mathbf{- 1 0 , 3 5 7} \\
{[-18,362 \text { to }-2,351]}\end{array}$ \\
\hline \multicolumn{4}{|l|}{ Chronicity } \\
\hline $\begin{array}{l}\text { Multiple episodes (vs. one } \\
\text { episode) }\end{array}$ & $\begin{array}{c}-3,375 \\
{[-9,721 \text { to } 2,968]}\end{array}$ & $\begin{array}{c}-1,699 \\
{[-8,004 \text { to } 4,604]}\end{array}$ & $\begin{array}{c}-2,706 \\
{[-10,939 \text { to } 5,525]}\end{array}$ \\
\hline
\end{tabular}

